Article

\title{
Collaborative Learning Based on Harry Potter for Learning Geometric Figures in the Subject of Mathematics
}

\author{
Antonio-José Moreno-Guerrero ${ }^{1, *(1)}$, Marina Rondón García ${ }^{2}$, Nazaret Martínez Heredia ${ }^{3}$ and \\ Antonio-Manuel Rodríguez-García 4 (D) \\ 1 Department of Didactics and School Organization, Faculty of Education, Economics and Technology of \\ Ceuta, University of Granada, 51001 Ceuta, Spain \\ 2 Sotogrande International School, 11310 Cádiz, Spain; mrondon@sis.gl \\ 3 Pedagogical Department, Faculty of Education Sciences, University of Granada, 18011 Granada, Spain; \\ narareth@ugr.es \\ 4 Department of Didactics and School Organization, Faculty of Education and Sport Sciences, University of \\ Granada, 52005 Melilla, Spain; arodrigu@ugr.es \\ * Correspondence: ajmoreno@ugr.es
}

Received: 21 January 2020; Accepted: 3 March 2020; Published: 6 March 2020

\begin{abstract}
Nowadays, education requires changes in the teaching and learning processes, through the implementation of innovative and motivating pedagogical actions, owing to the existing needs in society. Education, owing to the current needs of society, requires changes in the teaching and learning processes through the implementation of innovative and motivating pedagogical actions. The main objective of this study is to evaluate the effectiveness of the collaborative method, based on the Harry Potter theme, with respect to the traditional method in the first year of Obligatory Secondary Education for the learning of geometric figures in the subject of mathematics. For this purpose, a quasi-experimental, quantitative, descriptive, and correlational study has been designed, using a standardized questionnaire as a technique to collect information. The sample is composed of 236 students from the first year of Obligatory Secondary Education distributed in eight groups (four control and four experimental) from a public high school in the city of Cádiz (Spain). The tests carried out show that collaborative learning generates improvements in the attitudes and mathematical dimensions. Therefore, the collaborative method, developed by means of the Harry Potter theme for students in the first year of Compulsory Secondary Education in the subject of mathematics, causes a better attitude of the student towards the teaching and learning process. Furthermore, it facilitates the acquisition of mathematical contents related to geometry, which does not directly affect the students' grades because, although those of the experimental group are better than those obtained by the control group, the differences between the two are minimal.
\end{abstract}

Keywords: mathematics; teaching; learning; collaborative learning; education research

\section{Introduction}

The development of education is an essential pillar for being an advanced society [1]. Therefore, educational institutions are betting on the implementation of innovative teaching processes [2] and are trying to move away from traditional [3] and passive [4] didactic approaches. This is because innovative practices have a positive impact on the training of students [5-10], and thus on the social environment [11,12]. 


\subsection{Particularities of Collaborative Learning in Today's Education}

However, for the inclusion of alternative and innovative learning methods in the teaching-learning process to be appropriate, an effort is needed, both from those responsible for managing the educational centres [13] and from the teachers themselves [14], who must rethink the teaching processes [15] and where information and communication technologies are a means to achieve such innovation [16-18].

Among the various pedagogical actions considered innovative and that have demonstrated effective results in improving student learning [19-21] are collaborative teaching methods. These have become a more common practice in recent times in the processes of teaching and learning [22], thanks to their high educational potential [23].

We can define collaborative learning as learning that is carried out by two or more people [24], where-at certain times_resources are shared [25] or the different skills of the group members are required to be put into practice [26] to achieve academic achievements through interaction [27], exchanges of experience [28], or changes in roles within the group [29], as the actions of all members have an impact on the achievements of the rest [30]. The collaborative group requires mainly group projects [31], joint problem solving [32], discussions [33], and study teams [34], among others.

Certain studies show that social interactions do not emerge in the moment, but require a period of time in order to develop adequately [35], in addition to prior pedagogical training by teachers [36]. However, among the drawbacks of this method is the possible lack of commitment among the members of the group [37], an aspect that must be taken into account in order to overcome it if success is to be achieved in the training process [38].

The collaborative teaching method, which is positively valued by students $[39,40]$, improves interactions and communications among students [41,42]; encourages peer communication; and increases attitude [43], motivation [44], sense of community [45,46], the resolution of activities [47], the state of mind of the student [48], and autonomy [49], actively involving them in their learning process [50].

In the area of mathematics, the collaborative method is motivating for students [51], improving their attitude towards the teaching and learning process [52], as well as their competence in problem solving and study skills [53,54], although there is no evidence of improvement in students' grades [55].

In addiction, the scientific production that studies collaborative learning in the field of mathematics, there are studies that have shown that this method can improve the conditions for solving mathematical problems [54] or improve the dialectical capacity to explain the different steps taken to solve a problem or to explain the mathematical solutions obtained [51], or that teachers require adequate pedagogical skills to be able to use the collaborative learning, given that, if they do not have them, the method tends to fail [37].

\subsection{Definition of Study Dimensions}

This research will focus on the study of attitudinal and mathematical dimensions. The choice of these dimensions is justified in the analysis of previous works reported from the impact literature, where the influence caused by the application of collaborative learning in the pedagogical development of mathematics is studied [39-55]. Therefore, in order to follow the path followed in previous research, we have chosen to make use of these two dimensions.

To facilitate the understanding of the results presented in this research, a definition of the study variables is established:

- Motivation: Reflects the level of motivation of students during the performance of the training actions proposed by the teacher.

- Autonomy: Reveals the level of autonomy achieved and the individual capacities of the students in the different activities proposed.

- Collaboration: The level of teamwork achieved by students in the different learning tasks. 
- Participation: Shows the different types of interactions that can take place in the learning spaces, such as the interaction between the teacher and the students, between the students and the content of the teaching, and between the students themselves.

- $\quad$ Problem solving: Shows the level of ability of the student to solve the different actions involved in team work.

- Class time: The use of class time to work on the contents programmed by the teacher and that the student must assimilate in the classroom.

- Concepts: These are the contents developed and worked on with the students during the unit.

- Scientific data: The scientific data that were acquired during the practical application.

- Graphics: The graphic representations that the students have worked on during the development of the didactic unit.

- Results: The different actions and mathematical problems carried out for the development of the different contents presented in the didactic unit.

- Decisions: The decisions taken by the group when it comes to solving the different actions and pedagogical actions proposed.

- Qualifications: The grades reached by the students in the different evaluation tests carried out to verify the assimilation of the contents.

\section{Justification and Objectives of the Research}

The new trends in education and the need for an improvement in the teaching and learning process require new approaches and teaching methods that update the way we teach and learn [56].

In this research, we present a pedagogical method based on the collaborative methodology, associated to the Harry Potter theme, showing all the actions developed from the beginning to the end of the didactic unit, including the evaluation process, trying to enhance the formative development of the students $[57,58]$, especially in students in the first year of Obligatory Secondary Education, where they are in a moment of changes at the physiological and educational level [59].

In this study, besides giving continuity to educational practices related to the collaborative method in the teaching and learning processes, we tried to contrast the results obtained in the present study with those achieved in other research [60-63].

For all these reasons, the main objective of this study focuses on knowing the effectiveness of the collaborative method, based on the Harry Potter theme, as opposed to the traditional method in the first year of Obligatory Secondary Education. From this general objective, the following specific objectives are obtained: (1) What is the degree of motivation of the students? (2) What is the degree of autonomy of the students? (3) Does this method improve collaboration between students? (4) Does this method improve student participation? (5) What is the level of problem solving? (7) Does this method improve the level of learning of concepts, graphs, scientific data, and results? (8) Does this method increase the capacity of decision making in pedagogical actions? (9) How does this method influence the grades of the students?

\section{Methodology}

\subsection{Research Design}

The present study is quantitative, descriptive, and correlational [64], applying a quasi-experimental design with an experimental group (Ge), following the design already proposed in previous research [65]. The students are divided into eight groups, four of them make up the control group $\left(1^{\circ} \mathrm{A}, 1^{\circ} \mathrm{C}, 1^{\circ} \mathrm{E}\right.$, and $\left.1^{\circ} \mathrm{G}\right)$, which developed a collaborative teaching method, and the other four the experimental group $\left(1^{\circ} \mathrm{B}, 1^{\circ} \mathrm{D}, 1^{\circ} \mathrm{F}\right.$, and $\left.1^{\circ} \mathrm{H}\right)$, which followed a traditional-experimental teaching method (Table 1). The distribution of students in the previous groups could not be carried out randomly, as the centre only allowed the development of the study if the groups of students were maintained in the same way, so we applied a sampling method for convenience. In any case, the pedagogical criteria marked at the 
beginning of the course for the formation of the groups were based on the principle of equity, with a distribution of students per class according to their level of curricular competence. The collection of data was developed after the intervention.

Table 1. Description of the groups.

\begin{tabular}{lccccc}
\hline \multicolumn{1}{c}{ Group } & $\mathbf{n}$ & Composition & Pretest & Treatment & Postest \\
\hline 1-Control & 30 & Natural & - & - & $\mathrm{O}_{1}$ \\
2-Experimental & 30 & Natural & - & $\mathrm{X}$ & $\mathrm{O}_{2}$ \\
1-Control & 30 & Natural & - & - & $\mathrm{O}_{3}$ \\
2-Experimental & 30 & Natural & - & $\mathrm{X}$ & $\mathrm{O}_{4}$ \\
1-Control & 30 & Natural & - & - & $\mathrm{O}_{5}$ \\
2-Experimental & 30 & Natural & - & $\mathrm{X}$ & $\mathrm{O}_{6}$ \\
1-Control & 28 & Natural & - & - & $\mathrm{O}_{7}$ \\
2-Experimental & 29 & Natural & - & $\mathrm{X}$ & $\mathrm{O}_{8}$ \\
\hline
\end{tabular}

Note. Treatment was randomly assigned.

\subsection{Participants}

The study sample was composed of 236 students, by means of a convenience sampling, owing to the easy access to the subjects. According to impact studies reported in the specialized literature, for this type of research, the size of the sample is not a determining factor for conducting educational experiments [66,67].

The students are from the first year of Obligatory Secondary Education (ESO), from a public centre in the Autonomous Community of Andalusia, in the province of Cadiz. The learning experience took place during the first quarter of the 2019/2020 academic year, between 9 and 20 December 2019. All participants were informed of the objective of the study, and the corresponding permits were requested from the school management, as well as parental consent for the development of the activity. In this case, we received the acceptance of all students from first year of ESO, and there were no parents or students who refused to participate.

The participating sample is made up of $45 \%$ male students and $55 \%$ female students, aged between 12 and $14(\mathrm{M}=13, \mathrm{SD}=1.13)$, with $16 \%$ of students being repeaters and $3 \%$ having specific educational support needs.

\subsection{Instruments}

The instrument used was based on the questionnaire developed by the authors of [20], composed of 42 items, distributed in three dimensions-social, attitudinal, and mathematical. The socio-educational dimension was adapted to the characteristics of the method presented in this research. The questionnaire uses a Likert scale, composed of four items (1: None, 2: Few, 3: Enough, and 4: Completely).

The social dimension is composed of 17 items, where gender (1 item), age (1), religion (1), knowledge about collaborative learning ( 3 items), capacity of the centre to develop the collaborative learning method ( 3 items), and frequency of Information and communication technologies (ICT) use (8 items) are analysed. The attitudinal dimension is made up of 12 items, in which motivation (2 items), autonomy ( 2 items), collaboration ( 2 items), participation ( 2 items), resolution ( 2 items), and class time ( 2 items) are analysed. The mathematical dimension is composed of 13 items, distributed in concepts (2 items), scientific data (2 items), graphics ( 2 items), results (2 items), decision (2 items), and ratings (3 items).

The instrument followed several processes for its validity and reliability. Firstly, they applied the Delphi method, of qualitative validity, through 10 experts, with positive ratings $(\mathrm{M}=4.87$; $\mathrm{SD}=0.21 ; \min =1$ ). Subsequently, the statistics of Kappa by Fleiss and $\mathrm{W}$ by Kendall were applied, offering adequate indicators $(\mathrm{K}=0.85 ; \mathrm{W}=0.84)$. Then, it was quantitatively validated by exploratory factorial analysis with varimax rotation, the results of which $($ Bartlett $=2538.17 ; p<0.001$; 
Kaiser-Meyer-Olkin $=0.86$ ) are satisfactory. Finally, Cronbach's alpha $(0.88)$, the reliability of the compound (0.86), and the mean variance extracted $(0.83)$ were used, showing adequate metrics. Bearing in mind all the above, we can consider the instrument as valid and reliable.

\subsection{Variables}

The design of the study is divided into two types of variables: dependent and independent (Hernández et al., 2014), which will be coded to facilitate their understanding for the presentation of results. The independent variable is the one that is manipulated to know its effect on the dependent variable, so the collaborative method is the one considered as an independent variable (COOP).

The dependent variables are distributed in two dimensions: Dimension I. Attitudinal, composed with the variables motivation (MOT), autonomy (AUT), collaboration (COL), participation (PAR), resolution (RES), and class time (CTI), which have the intention of knowing the attitudes, motivations, and interests of the students in order to put into practice the teaching method; Dimension II. Mathematical, conformed by the variables concepts (CON), scientific data (SDA), graphics (GRA), results (RST), decision (DES), and ratings (RAT), which analyze the acquisition of the contents proposed in the area of mathematics, following the structure and contents marked in the questionnaire already elaborated by the authors of [20].

\subsection{Methodological Procedure}

The procedure developed at the methodological level in this study has followed several steps. First, we selected the sample. For this purpose, we presented the didactic proposal and the intentions of the study to an educational centre, which agreed to participate, after a detailed presentation of the actions to be developed. In return, they asked us to receive information about the results obtained and the detailed description of the pedagogical action.

Then, we established two pedagogical proposals for the teaching of the proposed didactic unit: one through the expository method, that is, through the traditional teaching method, where the teacher is a mere reproducer of contents and the students carry out each of the activities presented by the teacher, all of them being elaborated through the textbook and the workbook. On the other hand, the other was developed through the collaborative teaching method. Therefore, two types of groups were generated, the control group that developed the traditional pedagogical proposal, and the experimental group, which carried out the teaching method through cooperative groups.

Once the unit was concluded, the data collection process was carried out by means of a questionnaire, which was validated before the realization of this study. Finally, we carried out the statistical analysis that allowed the extraction of results and the subsequent establishment of conclusions to respond to the objectives set out.

\subsection{Didactic Proposal}

The following didactic proposal is based on the famous literary saga of J. K. Rowling, composed of a total of seven books: Harry Potter and the Philosopher's Stone (1997); Harry Potter and the Chamber of Secrets (1998); Harry Potter and the Prisoner of Azkaban (1999); Harry Potter and the Goblet of Fire (2000); Harry Potter and the Order of the Phoenix (2003); Harry Potter and the Mystery of the Prince (2005); and finally, Harry Potter and the Deathly Hallows (2007). This magical universe tells the story of Harry Potter, a young orphaned wizard raised by his cruel Muggle uncles who, at the age of eleven, receives a letter of admission to Hogwarts School of Witchcraft and Wizardry. Little by little, the young apprentice will discover his true identity and the great threat that terrorizes the world of witches and wizards: the evil Lord Voldemort, whom he will defeat along with his friends Hermione Granger and Ron Weasley.

The nature of the didactic unit requires that the operation of the magic school be studied in depth. At the beginning of the school term, all first-year students must participate in the Selection Ceremony, 
where a magic hat analyzes the personality and abilities of each student to assign them to one of the four houses into which the entire school is divided (Figure 1).

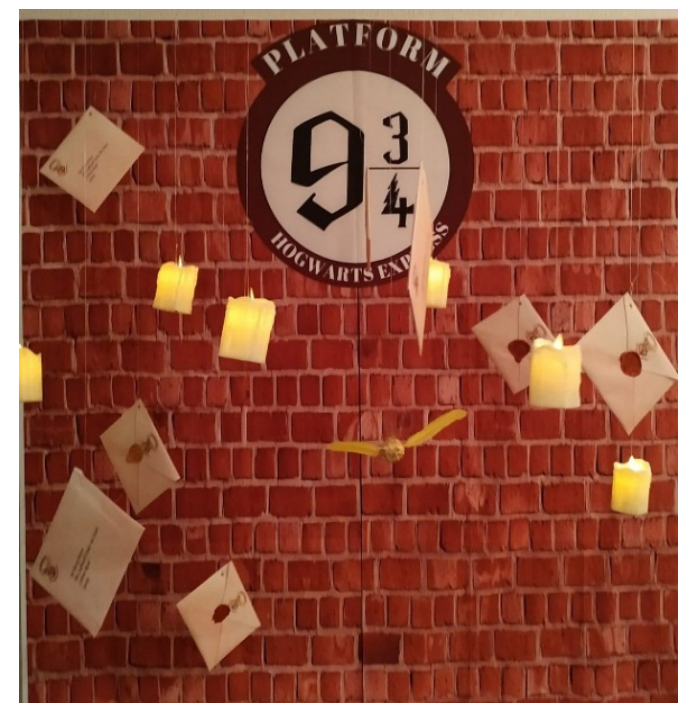

Figure 1. Letter of admission.

These houses bear the surname of one of the founders of the institution, and are represented by their own colours and symbols. To wit, the Gryffindor house, represented by a lion, is characterized by scarlet and gold; in the case of the Hufflepuff house, we find a badger, under the colors black and yellow; on the part of the Ravenclaw house (Figure 2), we appreciate an eagle, with the colors blue and bronze; and, finally, the Slytherin house, is symbolized by a snake, and its colors are green and silver.

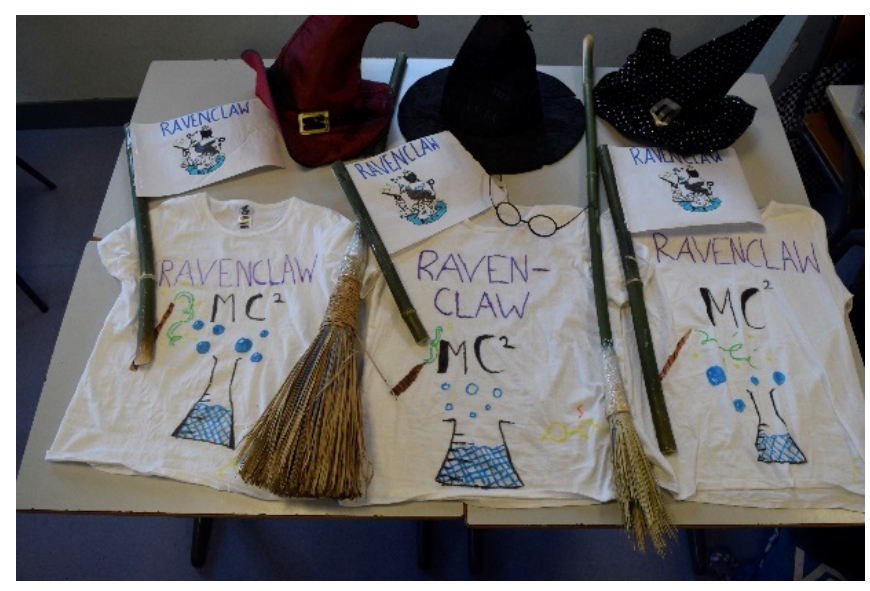

Figure 2. Ravenclaw team.

Throughout the course, the four houses try to get as many points as possible through good behaviour and academic achievement, bearing in mind that bad behaviour or poor performance by one member can lower the score for the whole house. At the end of the school year, all points are counted and the winners are awarded the House Cup (Figure 3).

In the first session of the chosen teaching unit, Topic 12: flat figures, we had to make sure that all the students were familiar with both the subject of the saga and the Hogwarts educational system. Once they were familiar with it, we divided the students into the aforementioned houses (four collaborative groups). To facilitate the management of the groups, a leader or team leader was also appointed. Once the groups were formed, the leaders went out to the blackboard to take one of the four letters of admission to Hogwarts, which, in addition to containing the welcome to the school and the list of 
school supplies, included the symbol of one of the houses. Thus, when the leader selected a letter of admission, he was choosing, in parallel, the house that would correspond to his team.

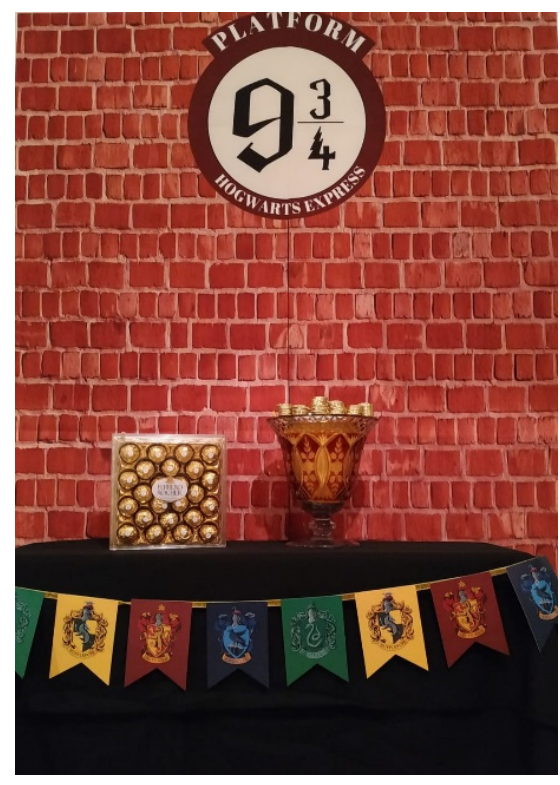

Figure 3. House Cup.

After assigning the houses, we customized the equipment so that, at all times, we knew which student belonged to which house. The leaders wore an identification card around their necks with the symbol of their house, while the rest of the members wore it as a pin attached to their jersey. Likewise, we let each house use its colors to distinguish itself from the rest in a personal, creative, and original way, whether it was with the colors of scarves, bracelets, flags, or other attire.

Afterwards, we explained to the students the working mechanics that we would adopt throughout the whole theme: the teacher would pose challenges and activities and each team would have to overcome them in the best possible way to get points on their scoreboard. The winning team would get one point for the exam and the Copa de las Casas (Table 2).

Table 2. Contents worked on during the sessions.

\begin{tabular}{|c|c|c|}
\hline Contents & Characteristics & Session \\
\hline Polygons & $\begin{array}{l}\text { Definition, properties, and classification } \\
\text { according to their number of sides and } \\
\text { according to their inner angles }\end{array}$ & $1-2$ \\
\hline Triangles & $\begin{array}{l}\text { Definition, properties, and classification } \\
\text { of their sides and angles. Principles of } \\
\text { equality, similarity, or distinction. The } \\
\text { Theorem of Pythagoras }\end{array}$ & $3-4$ \\
\hline Quadrilaterals & $\begin{array}{l}\text { Definition, properties, and classification } \\
\text { according to the parallelism of its sides: } \\
\text { parallelograms, trapezes, and trapezoids }\end{array}$ & $5-6$ \\
\hline $\begin{array}{l}\text { Construction of regular triangles } \\
\text { and polygons }\end{array}$ & Axes of symmetry & 7 \\
\hline $\begin{array}{l}\text { Straight lines and notable points of } \\
\text { a triangle }\end{array}$ & $\begin{array}{l}\text { Mediatrix-circle; bisector-incenter; } \\
\text { medium-baricenter; high-orthocenter }\end{array}$ & $8-9$ \\
\hline Circumference & $\begin{array}{l}\text { Definition, elements. Relative positions of } \\
\text { two circumferences and relative positions } \\
\text { of a line and a circle }\end{array}$ & 10-11 \\
\hline Circle and circular figures & $\begin{array}{l}\text { Main differences between circle and } \\
\text { circumference }\end{array}$ & 12 \\
\hline
\end{tabular}


The objectives set out in this teaching unit were as follows: (1) to encourage students to internalize the contents relating to flat figures; (2) to connect the contents of the subject with the real world, through the activities set out; (3) to learn to work in collaborative groups, raising questions and solving challenges among all colleagues; (4) to encourage participation and collaboration in the classroom; and (5) to propose activities where the main protagonist is the student.

In order to respect the Hogwarts procedure, we created four admission letters very similar to those described in Harry Potter and the Philosopher's Stone, which contained the welcome to the school and the list of necessary tools. In addition, we introduced the symbol of one of the houses in each letter, to simulate the selection ceremony described above. All these materials were available on Pinterest, all we did was download them, cut out the letters, and seal them with wax.

It was also necessary to create identification cards and emblems. The characteristic of this methodology is the competitiveness that is established between the teams, so it is essential that each student visually represents his or her home. To do this, we designed cards with the colors and symbols of the corresponding houses, which the leaders wore around their necks, differentiating them from the rest of the group. The rest of them wore the plasticized emblems attached to the jersey.

The scoreboard, which is attached in a later section, was projected at all times, with the intention that all groups were aware of their position and the points needed to beat their peers. In fact, it is a Word table showing the activities to be carried out, the points each one provides, and the score each house has achieved.

On the other hand, the activity Avada Kedavra is a game belonging to the last session that intends to "face" the leaders to win the last 10 points of the unit, so the ornamentation was a little more special. A plastic tablecloth was used with the Hogwarts emblem and the shields of the four houses, buttons of the mentioned colors, and the necessary geoplanes for the activity.

Finally, the long-awaited prize, the House Cup, consisted of a collection of golden snitches and a cup full of galleons. That is, a box of chocolates and a lot of chocolate coins.

The first 15-20 min of class were used to give a master explanation of the contents by the teacher. Afterwards, in each session, we proposed activities of different types depending on the needs of the moment: introduction, previous knowledge, development, consolidation, reinforcement, recovery, and extension. To summarize, we will highlight here only some of the consolidation activities, as they were the ones that provided points for the scoreboard.

\section{Activity 1. ¡Alohomora!}

The first activity proposed consisted of making a video that explained part of the agenda. The house that explained the content in the clearest and in the most organized and original way would get 10 points for its score.

- Gryffindor House. Polygons: definition, the elements that make it up (interior angle, vertex, side, diagonal, exterior angle, and so on), and classification according to their sides and angles.

- Hufflepuff House. Triangles: definition, properties, and classification according to their sides and angles, as well as Pythagorean Theorem.

- Ravenclaw House. Quadrilaterals: definition, properties, and classification according to the parallelism of their sides in parallelograms, trapezes, and trapezoids. Subdivision of each of them.

- Slytherin House. Circumference. Definition, elements that make it up, and classification according to the relative positions of two circles or relative positions of a line and a circle. The circle and circular figures.

\section{Activity 2. Expecto Patronum}

The following activity was based on two different challenges. Firstly, the students looked for famous brand logos made up of one of the flat figures studied. Thus, they had to identify the figure and recognize the elements that made it up. The team that found the most logos in the 20 min established would again get 5 points for their score. 
On the basis of these examples, the teams designed their own logo using the number of flat figures they deemed appropriate. The most innovative and creative logo would get another 5 points.

Activity 3. Sectumsempra

With the intention of highlighting the close relationship of geometry with the artistic world, the students chose an artistic manifestation where the flat figures were the protagonists. To do this, they had to search for information about the authors, works, or historical monuments selected, and identify the geometrical concepts that could be observed. Examples of this were the proposals of the Ravenclaw houses, with the analysis of the mosaics of the Alhambra (Granada, Spain), or the Slytherin house, with the interpretation of the work of Piet Mondrian.

\section{Activity 4. Avada Kedavra}

For the development of this game, we gathered four desks that were decorated with a tablecloth with Hogwarts motifs (Figure 4).

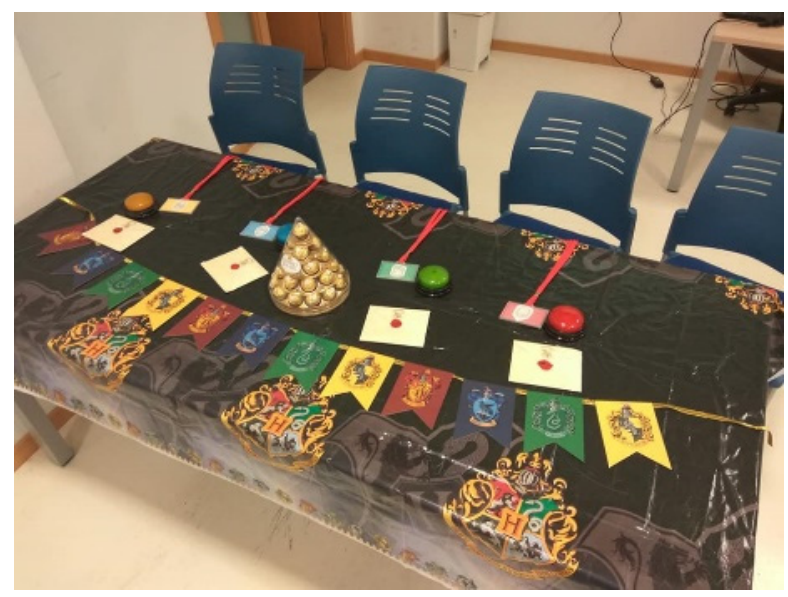

Figure 4. Activity Avada Kedavra.

- Ask! Each desk was fitted with a button in the colour of each house, that is, red, blue, yellow, and green. The activity was simple: the leaders, representing their houses, had to touch the button before the rest of their opponents and answer a series of questions correctly. The leader who answered the most questions would accumulate 5 points for the score.

- Geoplane. With rubber bands, the leaders had to build on the geoplane seven flat figures proposed by the professor. The winner would accumulate another 5 points.

To evaluate the performance of the students throughout the teaching unit, a marker was created (Table 3) where we reflected the houses or teams with their representative colours, the activities carried out, and the corresponding scores. Although we provided the points according to the relevant evaluation criteria, we tried to ensure that the difference between the teams was not too significant, as this could have caused disinterest or lack of motivation in some of the groups. Finally, the winning team was awarded the Copa de la Casas and one point for the written test.

Table 3. Group performance marker.

\begin{tabular}{cc}
\hline Activities & Points \\
\hline ¡Alohomora! & 10 \\
Expecto Patronum & 10 \\
Sectumsempra & 10 \\
Avada Kedavra & 10 \\
Behavior & 5 \\
\hline
\end{tabular}


The tools used for formative evaluation were both direct observation of the student and oral tests and rubrics, used mainly in activity 1 and 3.

\subsection{Data Analysis}

Data analysis was performed using IBM SPSS Statistics version 25.0. For the descriptive study, the statistics of mean (M), standard deviation (SD), asymmetry $\left(\mathrm{A}_{\mathrm{me}}\right)$, and kurtosis $\left(\mathrm{K}_{\mathrm{me}}\right)$ were used. The comparison of means was developed by means of the Student $t$-test, specifically the $t$-test for independent samples, differentiating the means given between the experimental group and the control group. In both cases, values lower than $p<05$ were considered as a significant difference, in addition to the $t$ statistics $\left(t_{n 1+n 2-2}\right)$, Cohen's $d$, and biserial correlation $\left(r_{x y}\right)$.

\section{Results}

The results shown in Table 4 provide the data related to the descriptive analysis. In this case, all the values of the control group are below 2, which marks levels between medium and low in the development of the teaching and learning process using the traditional method. On the other hand, with respect to the students of the experimental group, the average of the variables analyzed is above 2.5 , except for the ratings, where it is below 2 . Taking into account the values given by the asymmetry and kurtosis, a normal distribution is observed, as they are in the range of \pm 1.96 , marked by [68]. The standard deviation shows that the values given by the different students were similar, especially in the control group, something that does not occur in the variables COL, PAR, and CON of the experimental group, where the response variety is more dispersed. The kurtosis shown in the different variables is mainly platystic, except in the DES variables, which is leptocurtic, and the AUT, PAR, and GRA variables, which are mesocurtic, all of them belonging to the control group.

Table 4. Results obtained for the study variables in the control and experimental groups.

\begin{tabular}{|c|c|c|c|c|c|c|c|c|c|}
\hline \multirow[b]{2}{*}{ Variables } & \multirow[b]{2}{*}{$\mathrm{G}$} & \multicolumn{4}{|c|}{ Likert Scale $n(\%)$} & \multicolumn{4}{|c|}{ Parameters } \\
\hline & & None & Few & Enough & Completely & M & SD & $\mathrm{S}_{\mathrm{kw}}$ & $\mathrm{K}_{\mathrm{me}}$ \\
\hline \multirow[t]{2}{*}{ Motivation } & $\mathrm{C}$ & $41(34.7)$ & $49(41.5)$ & $25(21.2)$ & $3(2.5)$ & 1.92 & 0.812 & 0.450 & -0.595 \\
\hline & $\mathrm{E}$ & $20(16.8)$ & $40(33.6)$ & $36(3.03)$ & $23(19.3)$ & 2.52 & 0.990 & 0.021 & -1.019 \\
\hline \multirow[t]{2}{*}{ Autonomy } & $\mathrm{C}$ & $47(39.8)$ & $48(40.7)$ & $15(12.7)$ & $8(6.8)$ & 1.86 & 0.886 & 0.871 & 0.100 \\
\hline & $\mathrm{E}$ & $17(14.3)$ & $42(35.3)$ & $36(30.3)$ & $24(20.2)$ & 2.56 & 0.971 & 0.017 & -0.979 \\
\hline \multirow[t]{2}{*}{ Collaboration } & $\mathrm{C}$ & $49(41.5)$ & $43(36.4)$ & $23(19.5)$ & $3(2.5)$ & 1.83 & 0.830 & 0.601 & -0.561 \\
\hline & $\mathrm{E}$ & $22(18.5)$ & $35(29.4)$ & $39(32.8)$ & 23(19.3) & 2.53 & 1.007 & -0.05 & -1.060 \\
\hline \multirow[t]{2}{*}{ Participation } & $\mathrm{C}$ & $49(41.5)$ & $48(40.7)$ & $17(14.4)$ & $4(3.4)$ & 1.80 & 0.812 & 0.781 & 0.022 \\
\hline & $\mathrm{E}$ & $20(16.8)$ & $38(31.9)$ & $36(30.3)$ & $25(21)$ & 2.55 & 1.006 & -0.02 & -1.066 \\
\hline \multirow[t]{2}{*}{ Resolution } & $\mathrm{C}$ & $44(37.3)$ & $46(39)$ & $27(22.9)$ & $1(0.8)$ & 1.87 & 0.790 & 0.337 & -1.013 \\
\hline & $\mathrm{E}$ & $19(16)$ & $36(30.3)$ & $40(33.6)$ & $24(20.2)$ & 2.58 & 0.987 & -0.09 & -1.000 \\
\hline \multirow[t]{2}{*}{ Class time } & $\mathrm{C}$ & $52(44.1)$ & $43(36.4)$ & $19(16.1)$ & $4(3.4)$ & 1.79 & 0.836 & 0.776 & -0.184 \\
\hline & $\mathrm{E}$ & $18(15.1)$ & $42(35.3)$ & $37(31.1)$ & $22(18.5)$ & 2.53 & 0.964 & 0.031 & -0.945 \\
\hline \multirow[t]{2}{*}{ Concepts } & $\mathrm{C}$ & $45(38.1)$ & $49(41.5)$ & $18(15.3)$ & $6(5.1)$ & 1.87 & 0.853 & 0.753 & -0.051 \\
\hline & $\mathrm{E}$ & 23(19.3) & $33(27.7)$ & $37(31.1)$ & $26(21.8)$ & 2.55 & 1.039 & -0.07 & -1.147 \\
\hline \multirow{2}{*}{ Scientific data } & $\mathrm{C}$ & $54(45.8)$ & $43(36.4)$ & $19(16.1)$ & $2(1.7)$ & 1.74 & 0.789 & 0.718 & -0.366 \\
\hline & $\mathrm{E}$ & $16(13.4)$ & $39(32.8)$ & $43(36.1)$ & $21(17.6)$ & 2.58 & 0.934 & -0.07 & -0.844 \\
\hline \multirow[t]{2}{*}{ Graphics } & $\mathrm{C}$ & $51(43.2)$ & $45(38.1)$ & $16(13.6)$ & $6(5.1)$ & 1.81 & 0.860 & 0.881 & 0.103 \\
\hline & $\mathrm{E}$ & $14(11.8)$ & $43(36.1)$ & $37(31.1)$ & $25(21)$ & 2.61 & 0.949 & 0.001 & -0.941 \\
\hline \multirow[t]{2}{*}{ Results } & $\mathrm{C}$ & $58(49.2)$ & $36(30.5)$ & $21(17.8)$ & $3(2.5)$ & 1.74 & 0.842 & 0.794 & -0.399 \\
\hline & $\mathrm{E}$ & $15(12.6)$ & $46(38.7)$ & $35(29.4)$ & 23(19.3) & 2.55 & 0.945 & 0.085 & -0.912 \\
\hline \multirow[t]{2}{*}{ Decision } & $\mathrm{C}$ & $44(37.3)$ & $54(45.8)$ & $15(12.7)$ & $5(4.2)$ & 1.84 & 0.806 & 0.801 & 0.299 \\
\hline & $\mathrm{E}$ & $17(14.3)$ & $40(33.6)$ & $38(31.9)$ & $24(20.2)$ & 2.58 & 0.970 & -0.03 & -0.969 \\
\hline \multirow[t]{2}{*}{ Ratings 1} & $\mathrm{C}$ & $51(43.2)$ & $46(39)$ & $19(16.1)$ & $2(1.7)$ & 1.76 & 0.781 & 0.664 & -0.368 \\
\hline & $\mathrm{E}$ & $40(33.6)$ & $51(42.9)$ & $18(15.1)$ & $10(8.4)$ & 1.98 & 0.911 & 0.717 & -0.205 \\
\hline
\end{tabular}

${ }^{1}$ Established grade group (None: 1-4.9; Few: 5-5.9; Enough: 6-8.9; Completely: 9-10). 
The means offered by the control group and the experimental group differ substantially from each other, with a higher average value in the groups where the educational experience was developed through cooperative groups under the theme of Harry Potter than in the groups where a traditional teaching and learning process was applied. The distance between the variables of the control group and the experimental group is even, except in ARP, where the results are more similar (Figure 5).

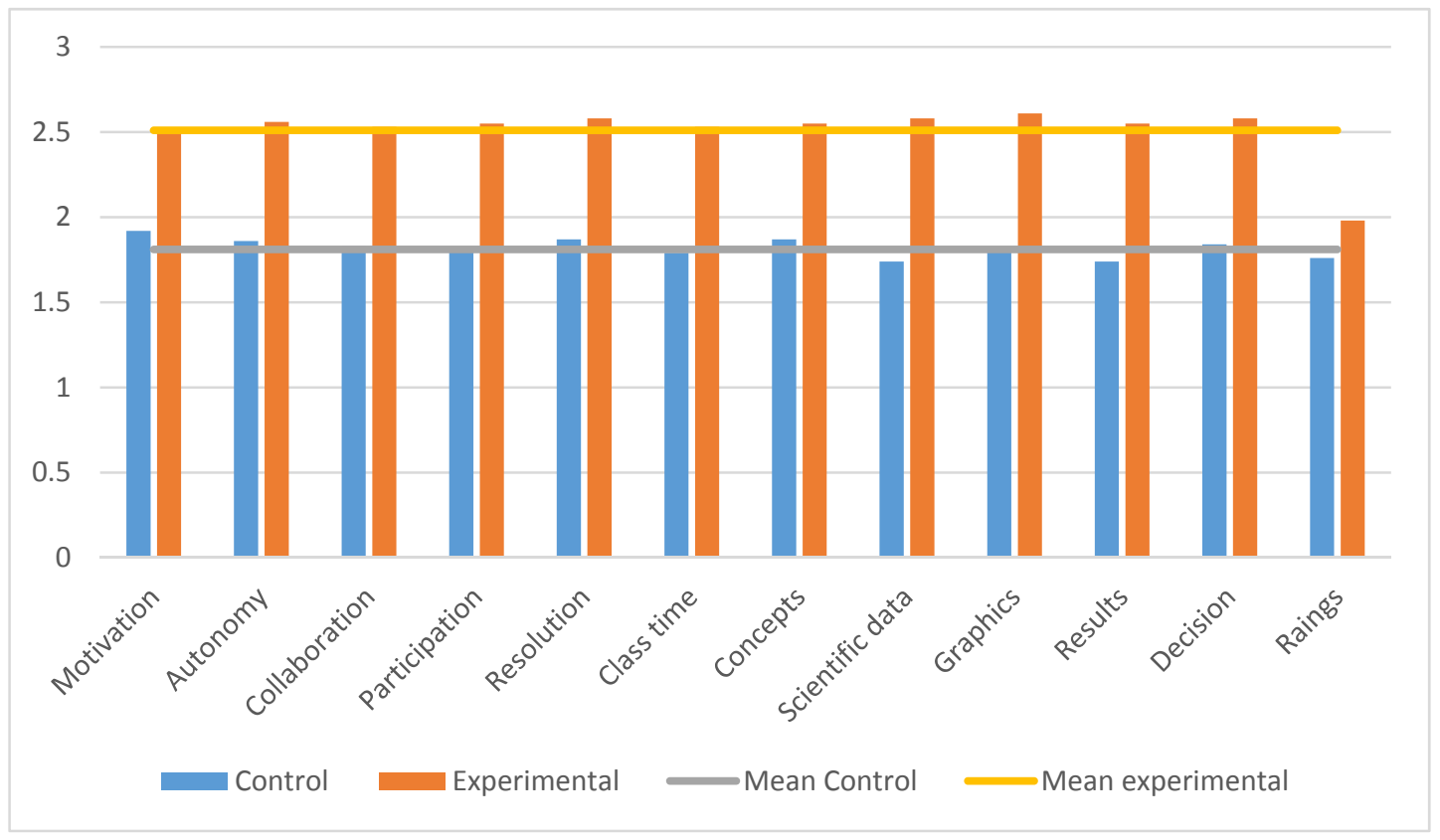

Figure 5. Comparison between control groups and experimental groups.

In order to know the value of independence of the values given between the traditional method of teaching in relation to the method of teaching based on the cooperative groups through the theme of Harry Potter, the statistical test of Student's $t$-test for independent samples was used. The results show significant differences in all the variables analyzed, with the $p$-value being below 0.01 , except in rating, where the significance ratio is below 0.05 . The strength of association presented between the variables, according to the biserial correlation, is at medium-low levels, given that the values are between 0.3 and 0.5 , except in RAT, where the correlation is low. On the basis of the values provided by Cohen's d, we can determine that the effect size is small (Table 5).

Table 5. Study of the value of independence between the control groups and the experimental groups.

\begin{tabular}{cccccc}
\hline Variables & $\mu(\mathbf{X 1 - X 2 )}$ & $\boldsymbol{t}_{\boldsymbol{n} \mathbf{1 + n 2 - 2}}$ & $\mathrm{Df}$ & $\boldsymbol{d}$ & $\boldsymbol{r}_{\boldsymbol{x}}$ \\
\hline Motivation & $-0.606(1.92-2.52)$ & -5.151 & 235 & 0.037 & $0.318^{* *}$ \\
Autonomy & $-0.699(1.86-2.56)$ & -5.787 & 235 & 0.075 & $0.353^{* *}$ \\
Collaboration & $-0.699(1.83-2.53)$ & -5.832 & 235 & 0.058 & $0.355^{* *}$ \\
Participation & $-0.758(1.80-2.55)$ & -6.386 & 235 & 0.059 & $0.384^{* *}$ \\
Resolution & $-0.707(1.87-2.58)$ & -6.088 & 235 & 0.045 & $0.369^{* *}$ \\
Class time & $-0.741(1.79-2.53)$ & -6.327 & 235 & 0.103 & $0.381^{* *}$ \\
Concepts & $-0.682(1.87-2.55)$ & -5.523 & 235 & 0.018 & $0.339^{* *}$ \\
Scientific data & $-0.843(1.74-2.58)$ & -7.503 & 235 & 0.105 & $0.439^{* *}$ \\
Graphics & $-0.808(1.81-2.61)$ & -6.874 & 235 & 0.109 & $0.409^{* *}$ \\
Results & $-0.817(1.74-2.55)$ & -7.029 & 235 & 0.166 & $0.417^{* *}$ \\
Decision & $-0.741(1.84-2.58)$ & -6.399 & 235 & 0.040 & $0.385^{* *}$ \\
Ratings ${ }^{\text {a }}$ & $-0.220(1.76-1.98)$ & -1.999 & 235 & 0.056 & $0.129^{*}$ \\
\hline
\end{tabular}

Note. ${ }^{* *}=$ the correlation is significant at the 0.01 level; ${ }^{*}=$ correlation is significant at the 0.05 level; n.s. $=$ not significant; ${ }^{a}=$ established grade group (None: 1-4.9; Few: 5-5.9; Enough: 6-8.9; Completely: 9-10). 


\section{Discussion}

The present research offers us a contrast, as far as the study variables are concerned, between the traditional-expositive method with respect to the collaborative method, given that all of them were superior in the experimental group with respect to the control group. This allows us to affirm that the collaborative method, using the Harry Potter theme, is more effective in comparison with the traditional method for teaching geometrically related content, as already pointed out by other researchers $[39,40]$. Furthermore, as can also be seen in other works, the collaborative method generated improvements in the attitudinal dimension [52], focusing on motivation [44,51], autonomy [49], collaboration [41,42], participation [50], resolution [47], and class time. In relation to the mathematical dimension, the fact of using an active teaching method, in which the student is the centre of his or her teaching and learning process, meant an improvement in the acquisition of concepts, scientific data, graphs, results, and outcomes to be adopted [20]. In contrast, although there were better academic results in the experimental group with respect to the control group, the differences were minimal [55].

The students who developed the educational experience through collaborative learning were motivated during all the sessions, showing autonomy in the development of the proposed activities, collaborating with each other for the development of the different pedagogical actions, actively participating in the teaching and learning process, and solving problems as a team. In addition, the feeling shown by the students in each of the sessions was that time passed quickly. At the end of each class, most indicated that time had passed quickly. This was not observed during the development of the sessions in the groups that used the expository method. With respect to the mathematical aspects of the unit (concepts, data, scientists, graphs, results, and decisions), it did not require constant and continuous repetition, something that was needed, on several occasions, by the students where the expository method was applied.

In all the variables of study, significant differences are shown, having greater inequalities in the mathematical dimension, mainly in scientific data, graphics, and results; thus not in the attitudinal one, where in all the variables, pairs were shown. On the other hand, the grades obtained by the students were not so significant with respect to the rest of the variables, with the difference between the groups being very low. These results are associated with other studies of similar characteristics, where the use of the collaborative method provides good results [23].

This shows that it is necessary to apply active, innovative teaching methods, where the students are the centre of attention, becoming responsible for their training process, while the teacher must be the guide that orients them during the whole process, thus generating changes at the educational level that will later provoke changes at the social level [1,11].

\section{Conclusions}

We conclude that collaborative learning, through the theme of Harry Potter in the field of mathematics, improves motivation, autonomy, collaboration, participation, and problem solving. It reduces the sense of time for students in the teaching and learning process. It also facilitates the acquisition of pedagogical aspects related to mathematics, including concepts, scientific data, graphics, results, and decisions. This does not happen with students who develop an expository teaching method, where all these aspects are less valued. Finally, with respect to student grades, we observe that those students who use collaborative learning present better results, although there are no great differences over those students who have used the traditional method.

The prospective of this research is to offer a teaching method, based on the collaborative teaching method and founded on the theme of Harry Potter, with a detailed description of it so that it can serve as a reference and basis for other teachers who want to develop teaching and learning processes of similar characteristics, both in the subject of mathematics and in others that they consider.

The limitations of the study focus on the sampling applied in this study, this being for convenience, as there was no possibility of modifying the components of each of the groups, given the period in which the research was carried out. It should also be borne in mind among the limitations that the 
results obtained were applied to a specific population, and thus the extrapolation of the data obtained should be taken with caution. As a future line of research, we propose the development of this teaching method in other populations and in other subjects, in order to be able to compare the results obtained with those achieved in this research.

Author Contributions: Conceptualization, A.-M.R.-G., A.-J.M.-G., and N.M.H.; methodology, M.R.G.; software, A.-J.M.-G. and A.-M.R.-G.; validation, A.-J.M.-G.; formal analysis, N.M.H. and A.-J.M.-G.; investigation, N.M.H., A.-J.M.-G., M.R.G., and A.-M.R.-G.; data curation, M.R.G., N.M.H., and A.-J.M.-G.; writing-original draft preparation, N.M.H., A.-J.M.-G., M.R.G., and A.-M.R.-G.; writing-review and editing, N.M.H., A.-J.M.-G., M.R.G., and A.-M.R.-G.; visualization, M.R.G. and N.M.H.; supervision, M.R.G., N.M.H., and A.-J.M.-G. All authors have read and agreed to the published version of the manuscript.

Funding: This research received no external funding.

Acknowledgments: To the researchers of the research group AREA (HUM-672). Research group by belonging to the Ministry of Education and Science of the Junta de Andalucía and based in the Department of Didactics and School Organization of the Faculty of Education Sciences of the University of Granada.

Conflicts of Interest: The authors declare no conflict of interest.

\section{References}

1. Martínez, S. Teaching innovation projects: Fundamental features to their on design, implementation and evaluation. Rev. Cienc. Pedag. Innov. 2019, 7, 95-103. [CrossRef]

2. Supermane, S. Transformational leadership and innovation in teaching and learning activities: The mediation effect of knowledge management. Inf. Discov. Deliv. 2019, 47, 242-250. [CrossRef]

3. Kars-Unluoglu, S. How do we educate future innovation managers? Insights on innovation education in MBA syllabi. Innov. Manag. Policy Pract. 2016, 18, 74-98. [CrossRef]

4. Goolsarran, N.; Hamo, C.E.; Lu, W.H. Using the jigsaw technique to teach patient safety. Med. Educ. Online 2020, 25, 1-5. [CrossRef] [PubMed]

5. Killen, C.P. Three dimensions of learning: Experiential activity for engineering innovation education and research. Eur. J. Eng. Educ. 2015, 40, 476-498. [CrossRef]

6. Li, G.; Wang, F. Research on art innovation teaching platform based on data mining algorithm. Clust. Comput. J. Netw. Softw. Tools Appl. 2019, 22, 13867-13872. [CrossRef]

7. Ho, P.A.; Girgis, C.; Rustad, J.K.; Noordsy, D.; Stern, T.A. Advancing the mission of consultation-liaison psychiatry through innovation in teaching. Psychosomatics 2019, 60, 539-548. [CrossRef]

8. Soltis, N.A.; McNeal, K.S.; Forbes, C.T.; Lally, D. The relationship between active learning, course innovation, and teaching Earth systems thinking: A structural equation modeling approach. Geosphere 2019, 15, 1703-1721. [CrossRef]

9. Luque, A.M. Ways of otherness in an institutional history teaching innovation experiences for jurists and political scientist. E Leg. Hist. Rev. 2019, 30,1-20.

10. Beekman, M.; Emani, V.K.; Wolford, R.; Hanson, K.; Wickham, G.; Aiyer, M. Patient safety morning report: Innovation in teaching core patient safety principles to third-year medical students. J. Med Educ. Curric. Dev. 2019, 6, 1-6. [CrossRef]

11. Bravo, M.J.; Ortuno, M.A.; Valmana, A.; Vizcaino, J.; Rodríguez, R.; Ruiz, M.E.; Salazar, M.; Vallejo, G.; Osaba, M.E. IVRA: Romans, Visigoths and Byzantines. An experience of teaching innovation in the key of gender. Rev. Educ. Derecho 2019, 1-34.

12. Fidalgo, C.; Collado, S.; Senis, J. From simulation to reality: Improvement of student performance in the TFM through a teaching innovation project. Rev. Electrón. Interuniv. Form. Profr. 2019, 22, 157-171. [CrossRef]

13. Collier, M.; Trauer, E.; Perassi, R.; Costa, E. Interdisciplinarity, design thinking, and innovation in public spaces: A teaching experience in florianopolis botanical garden park. Risus J. Innov. Sustain. 2019, 10, 86-97. [CrossRef]

14. Androutsos, A.; Brinia, V. Developing and piloting a pedagogy for teaching innovation, collaboration, and co-creation in secondary education based on design thinking, digital transformation, and entrepreneurship. Educ. Sci. 2019, 9, 113. [CrossRef] 
15. Van Assche, N.; Fickl, S.; Francisco, H.; Gurzawska, K.; Milinkovic, I.; Navarro, J.M.; Torsello, F.; Thoma, D.S. Guidelines for development of implant dentistry in the next 10 years regarding innovation, education, certification, and associations. Clin. Oral Implant. Res. 2018, 29, 568-575. [CrossRef]

16. Guardia, J.J.; Del Olmo, J.L.; Roa, I.; Belanga, V. Innovation in the teaching-learning process: The case of Kahoot! Horizon 2019, 27, 35-45. [CrossRef]

17. Chou, C.M.; Shen, C.H.; Hsiao, H.C.; Shen, T.C. Factors influencing teachers' innovative teaching behaviour with information and communication technology (ICT): The mediator role of organisational innovation climate. Educ. Psychol. 2019, 39, 65-85. [CrossRef]

18. Campos, N.; Ramos, M.; Moreno, A.J. Virtual reality and motivation in the educational context: Bibliometric study of the last twenty years from Scopus. Alteridad Rev. Educ. 2020, 15, 47-60. [CrossRef]

19. López, D.; Calonge, A.; Rodríguez, T.; Ros, G.; Lebron, J.A. Using gamification in a teaching innovation project at the University of Alcala: A new approach to experimental science practices. Electron. J. Learn. 2019, 17, 93-106. [CrossRef]

20. López, J.; Fuentes, A.; López, J.A.; Pozo, S. Formative transcendence of flipped learning in mathematics students of secondary education. Mathematics 2019, 7, 1226. [CrossRef]

21. Salas-Rueda, R.A. Use of the TPACK model as an innovation tool for the teaching-learning process on mathematics. Perspect. Educ. 2018, 57, 1-24. [CrossRef]

22. Hofmann, R.; Mercer, N. Teacher interventions in small group work in secondary mathematics and science lessons. Lang. Educ. 2016, 30, 400-416. [CrossRef]

23. Zhang, S.; Wen, Y.; Liu, Q. Exploring student teachers? Social knowledge construction behaviors and collective agency in an online collaborative learning environment. Interact. Learn. Environ. 2019, 1-13. [CrossRef]

24. Kerhani, P.; Kaveh, M.H.; Faghih, S.; Salehi, M. Improving diet quality among adolescents, using health belief model in a collaborative learning context: A randomized field trial study. Health Educ. Res. 2019, 34, 279-288. [CrossRef]

25. Acosta, R.; Martín-García, A.V.; Hernández, A. Use of the collaborative learning methodologies with ICT: An analysis based on the teachers' beliefs. Digit. Educ. Rev. 2019, 35, 309-323.

26. Van Leeuwen, A.; Janssen, J. A systematic review of teacher guidance during collaborative learning in primary and secondary education. Educ. Res. Rev. 2019, 27, 71-89. [CrossRef]

27. Isohatala, J.; Naykki, P.; Jarvela, S. Cognitive and socio-emotional interaction in collaborative learning: Exploring fluctuations in students' participation. Scand. J. Educ. Res. 2019, 1-21. [CrossRef]

28. Alghasab, M.; Hardman, J.; Handley, Z. Teacher-Student interaction on wikis: Fostering collaborative learning and writing. Learn. Cult. Soc. Interact. 2019, 21, 1-11. [CrossRef]

29. Voupala, E.; Naykki, P.; Isohatala, J.; Jarvela, S. Knowledge co-construction activities and task-related monitoring in scripted collaborative learning. Learn. Cult. Soc. Interact. 2019, 21, 1-16. [CrossRef]

30. Maqtary, N.; Mohsen, A.; Bechkoum, K. Group formation techniques in computer-supported collaborative learning: A systematic literature review. Technol. Knowl. Learn. 2019, 24, 169-190. [CrossRef]

31. Jung, J.; Shin, Y.; Zumbach, J. The effects of pre-training types on cognitive load, collaborative knowledge construction and deep learning in a computer-supported collaborative learning environment. Interact. Learn. Environ. 2019, 1-13. [CrossRef]

32. Boulton, H. Crossing boundaries: The affordances of new technologies in supporting a collaborative learning environment for doctoral students learning transnationally. Technol. Pedag. Educ. 2019, 28, 255-267. [CrossRef]

33. Hirsh, A.; Segolsson, M. Enabling teacher-driven school-development and collaborative learning: An activity theory-based study of leadership as an overarching practice. Educ. Manag. Adm. Leadersh. 2019, 47, 400-420. [CrossRef]

34. Hautala, J.; Schmidt, S. Learning across distances: An international collaborative learning project between Berlin and Turku. J. Geogr. High. Educ. 2019, 43, 181-200. [CrossRef]

35. Schnaubert, L.; Bodemer, D. Providing different types of group awareness information to guide collaborative learning. Int. J. Comput. Support. Collab. Learn. 2019, 14, 1-45. [CrossRef]

36. Williams, E.A.; Zwolak, J.P.; Dou, R.; Brewe, E. Linking engagement and performance: The social network analysis perspective. Phys. Rev. Phys. Educ. Res. 2019, 15, 1-15. [CrossRef] 
37. Gomez, L.F. Intention and pedagogical competence: Use of collaborative learning in the subject of mathematics in Secondary school. Propósitos Represent. 2016, 4, 157-179. [CrossRef]

38. Zhang, X.; Meng, Y.; Ordóñez, P.; Sun, Y. Learning analytics in collaborative learning supported by Slack: Fromthe perspective of engagement. Comput. Hum. Behav. 2019, 92, 625-633. [CrossRef]

39. Hargreaves, E.; Elhawary, D.; Mahgoub, M. 'One girl had a different idea': Children's perspectives on learning and teaching models in the traditional classroom. Education 2020, 48, 97-99. [CrossRef]

40. Simons, M.; Baeten, M.; Vanhees, C. Team teaching during field experiences in teacher education: Investigating student teachers' experiences with parallel and sequential teaching. J. Teach. Educ. 2020, 71, 24-40. [CrossRef]

41. Tissenbaum, M. I see what you did there! Divergent collaboration and learner transitions from unproductive to productive states in open-ended inquiry. Comput. Educ. 2020, 145, 1-15. [CrossRef]

42. Domingo-Coscollola, M.; Bosco, A.; Carrasco, S.; Sánchez, J.A. Fostering teacher's digital competence at university: The perception of students and teachers. RIE Rev. Investig. Educ. 2020, 38, 167-182. [CrossRef]

43. Hsieh, Y.C. Learner interactions in face-to-face collaborative writing with the support of online resources. RECALL 2020, 32, 85-105. [CrossRef]

44. Troussas, C.; Krouska, A.; Sgouropoulou, C. Collaboration and fuzzy-modeled personalization for mobile game based learning in higher education. Comput. Educ. 2020, 144, 1-18. [CrossRef]

45. Chatterjee, R.; Correia, A.P. Online students' attitudes toward collaborative learning and sense of community. Am. J. Distance Educ. 2019, 1-16. [CrossRef]

46. Wilson, K.F.; Wilson, K. Collaborate to graduate? What works and why? High. Educ. Res. Dev. 2019, 38, 1504-1518. [CrossRef]

47. Asino, T.I.; Pulay, A. Student perceptions on the role of the classroom environment on computer supported collaborative learning. Techtrends 2019, 63, 179-187. [CrossRef]

48. Volet, S.; Seghezzi, C.; Ritchie, S. Positive emotions in student-led collaborative science activities: Relating types and sources of emotions to engagement in learning. Stud. High. Educ. 2019, 44, 1734-1746. [CrossRef]

49. Bers, M.U.; González-González, C.; Armas-Torres, U. Coding as a playground: Promoting positive learning experiences in childhood classrooms. Comput. Educ. 2019, 138, 130-145. [CrossRef]

50. Rojprasert, S.; Neanchaleay, J.; Boonlue, S.; Sinlarat, P. Designing and implementing constructionist learning in a blended advertising photography course. Int. J. Technol. Enhanc. Learn. 2020, 12, 20-37. [CrossRef]

51. Vogel, F.; Kollar, I.; Ufer, S.; Reicersdorfer, E.; Reiss, K.; Fischer, F. Developing argumentation skills in mathematics through computer-supported collaborative learning: The role of transactivity. Instr. Sci. 2016, 44, 477-500. [CrossRef]

52. Huang, C.S.J.; Su, A.Y.S.; Yang, S.J.H.; Liou, H.H. A collaborative digital pen learning approach to improving students' learning achievement and motivation in mathematics courses. Comput. Educ. 2017, 107, 31-44. [CrossRef]

53. Cornick, J.; Guy, G.M.; Beckford, I. Integrating study skills and problem solving into remedial mathematics. Teach. Math. Appl. 2015, 34, 83-90. [CrossRef]

54. Retnowati, E.; Ayres, P.; Sweller, J. Can collaborative learning improve the effectiveness of worked examples in learning mathematics? J. Educ. Psychol. 2017, 109, 666-679. [CrossRef]

55. Chen, C.M.; Li, M.C.; Chen, T.C. A web-based collaborative reading annotation system with gamification mechanisms to improve reading performance. Comput. Educ. 2020, 144, 1-17. [CrossRef]

56. Moreno, A.J. Estudio bibliométrico de la producción científica sobre la inspección educativa. REICE Rev. Iberoameriocana Calid. Efic. Cambio Educ. 2019, 17, 23-40. [CrossRef]

57. Hinojo, F.J.; Aznar, I.; Romero, J.M.; Marín, J.A. Influencia del aula invertida en el rendimiento académico: Una revisión sistemática. Campus Virtuales 2019, 8, 9-18.

58. Sola, T.; Aznar, I.; Romero, J.M.; Rodríguez, A.M. Eficacia del método flipped classroom en la universidad: Meta-Análisis de la producción científica de impacto. REICE 2019, 17, 25-38. [CrossRef]

59. Moreno, A.J. Estudio bibliométrico de la producción científica en web of science: Formación profesional y blended learning. Pixel Bit. Rev. Medios Educ. 2019, 56, 149-168. [CrossRef]

60. Stanley, D.; Zhang, Y.J. Collaborative learning on online business education: Evidence from a field experiment. J. Educ. Bus. 2020, 1-7. [CrossRef]

61. Langset, I.D.; Jacobsen, D.Y.; Haugsbakken, H. Digital professional development: Towards a collaborative learning approach for taking higher education into the digitalized age. Nord. J. Digit. Lit. 2018, 13, 24-39. [CrossRef] 
62. Kaldirim, A.; Tavsanli, O.F. The effect of collaborative learning approach on students' academic achievement in Turkish courses in Turkey: A meta-analysis study. Egit. Bilim Educ. Sci. 2018, 43, 185-208. [CrossRef]

63. McNaughton, J.; Crick, T.; Joyce-Gibbons, A.; Beauchamp, G.; Young, N.; Tan, E. Facilitating collaborative learning between two primary schools using large multi-touch devices. J. Comput. Educ. 2017, 4, 307-320. [CrossRef]

64. Hernández, R.; Fernández, C.; Baptista, M.P. Metodología de la Investigación, 6th ed.; McGraw Hill: Madrid, Spain, 2014; pp. 129-168.

65. Pozo, S.; López, J.; Moreno, A.J.; López, J.A. Impact of educational stage in the application of flipped learning: A contrasting analysis with traditional teaching. Sustainability 2019, 11, 5968. [CrossRef]

66. Chou, P.N.; Feng, S.T. Using a tablet computer application to advance High School students' laboratory learning experiences: A focus on electrical engineering education. Sustainability 2019, 11, 381. [CrossRef]

67. Yilmaz, A.; Soyer, F. Effect of physical education and play applications on school social behaviors of mild-level intellectually disabled children. Educ. Sci. 2018, 8, 89. [CrossRef]

68. Jöreskog, K.G. Analysis of Ordinal Variables 2: Cross-Sectional Data; Text of the Workshop "Structural Equation Modelling with LISREL 8.51"; Friedrich-Schiller-Universität Jena: Jena, Germany, 2001; pp. 116-119.

(C) 2020 by the authors. Licensee MDPI, Basel, Switzerland. This article is an open access article distributed under the terms and conditions of the Creative Commons Attribution (CC BY) license (http://creativecommons.org/licenses/by/4.0/). 